\title{
Swedish Crime Fiction and Study Abroad: Literature, Politics and the Foreigner
}

\section{Joseph Michael Ellis}

Wingate University

\begin{abstract}
:
This paper highlights the use of Swedish crime fiction in the classroom to teach politics, especially issues related to immigration and the role of being "foreign". Furthermore, the paper explores how Swedish crime fiction can be incorporated into a study abroad course, examining one such study abroad - known as W'International - on our campus. I argue that Swedish crime fiction novels make for a perfect venue to explore an array of political problems and challenges, and a palatable way for students unfamiliar with Sweden or crime fiction to relate to real world issues.
\end{abstract}

\section{Introduction}

On October 14th, 2016, three members of a Kansas militia group were arrested when F.B.I. agents uncovered a terror plot, whereby members of the group planned to bomb a housing complex home to several Somali immigrants in western Kansas (Smith 2016). The story spotlighted the ongoing American conversation about the place of immigration and refugees in society, and also a growing concern over anti-immigrant and anti-Muslim backlash taking hold more generally. For example, in Canada in early 2017, a young, white, French-Canadian student opened fire at a Quebec City mosque, killing six worshippers.

Long before fears of Islamic terrorism and large-scale immigration gripped the United States, however, a public dialogue about immigrants was already underway in Sweden, beginning in the early 1990s with the publication of Henning Mankell's first novel in the Kurt Wallander series, entitled, Faceless Killers. In it, an older couple are killed, and the last words spoken by the dying wife are heard to be: foreigner. This sets the tone for the text, and the direction of the novel. Did a foreigner kill the elderly couple, and if so, what does it mean not only for this rural village, but also the future of Sweden? As the narrative develops we find out that, yes, a foreigner did kill them, but not who we might expect, and for reasons that do not appear straightforward. However, this did not stop two Swedish skinheads in the novel from setting fire to a Somali refugee camp (for "payback") even though the Somalis in question had nothing to do with the crime (Mankell 2003, 101). The 2016 incident in western Kansas, and the fictional account in Mankell's text, were nearly identical. Luckily in the case of Kansas, no property or people were harmed by the would-be terrorists.

In Spring 2016, I had the opportunity to teach a study abroad course on Swedish crime fiction, incorporating texts like Mankell's into a far-reaching discussion on issues such as immigration, the plight of the foreigner, and the presence of racism in society. The course - known as W'International on our campus - is a two-credit hour class in which particular subject matter and concepts are studied once a week for a semester, and then commences with a ten-day study abroad upon conclusion of the in-class assignments. We analyzed three texts in class in preparation for our journey to Sweden: Mankell's Faceless Killers, Stieg Larsson's The Girl With the Dragon Tattoo, and 
Camilla Läckberg's The Ice Princess. Why did a political scientist like myself approach the study of Sweden through novels, and how did such an approach facilitate learning among a class of students who knew next to nothing about Sweden, Swedish crime fiction, or Swedish politics?

For non-Swedes and those outside Scandinavia, crime fiction novels have been a critical gateway to understanding the politics, culture and problems of Northern Europe and Scandinavia. This is true not only for novices to Scandinavia, but also faculty and students engaged in teaching and scholarship on the subject. Though the novels may be fiction, many novels include material worthy of investigation by scholars in disciplines beyond the traditional study of literature. Scholars in the social sciences, for example, are prepared to ask a number of unique questions about crime fiction, including but not limited to the origin of the crime itself, the actors involved in the crime, and the political backdrop under which these crimes take place. Novels generally do not develop in isolation to the societies in which they were written. The crime fiction novel, in particular, stands at the intersection of both a literary contribution, as well as text which offers political and social commentary.

This essay highlights an approach to using Swedish crime fiction as a pedagogical tool to understand politics in Sweden, especially in preparation for in-country study. First, I will provide an overview of the W'International study abroad program on our campus; its history and mission. Second, the essay will discuss several prominent themes that come out of Swedish crime fiction. Understanding what it means to be a "foreigner" was a significant question which guided the course.

Lastly, I provide an overview of the texts used in the course, and how these particular texts can be incorporated into the classroom setting. The goal of this essay is to provide a model from which other social science faculty can use crime fiction in the classroom to teach broader lessons about Swedish politics and culture. As prominent Swedish crime novelist Åke Edwardson argued: "[In Sweden] it is not so much an obsession with crime; it's using crime to take a good look at the society we are living in" (Ames 2010).

\section{W'International: History and Mission}

In 1978, Wingate University initiated what became known as the "W'International" program, a ten-day study abroad program for Juniors, with costs paid entirely by the University. At the time, Wingate enrolled students from very rural parts of North and South Carolina. Most students coming to Wingate would have had almost no exposure to international travel, and W'International might have been their only chance to experience such an opportunity. Initially, Wingate had one study abroad destination - London, England - and two chartered planes flew directly from Charlotte to London. As the student body grew, and the program matured, changes were made, including adding a more rigorous classroom academic component, and expanding the destinations beyond London, to include other parts of Europe, Asia, Africa and South America. And though students now pay a modest $\$ 1,000$ to participate, the W'International program is recognized around campus as one of the crown jewels of the undergraduate experience.

Almost a year-and-a-half in advance of our travel, I submitted an application to study Swedish crime fiction, coupled with a subsequent abroad experience to tour Stockholm, Gothenburg, and 
Fjällbacka. ${ }^{1}$ Once the proposal was accepted (it is a competitive process), I previewed the W'International course before the student body in anticipation of sign-up day. On average, Wingate offers seven to eight W'International offerings, generally three in the Fall semester, and four in the Spring semester. Upon signing-up for their preferred W'International students camp out to save their spot in the course. (We joke at Wingate that while students at other universities camp out for athletic events, our students camp out for study abroad).

My Swedish crime fiction course enrolled 26 students, none of whom had travelled to Sweden before, or studied Sweden in a meaningful way. It is the third time I had participated in a W'International. The first two courses were a travel experience to the Baltic States, my main research interest. Like many throughout the world, however, I became captivated by Stieg Larsson's Girl with the Dragon Tattoo (GWTDT) series and what it purported to say about Swedish politics and culture. As of 2012, roughly 26 million copies of the GWTDT series (also known as the Millennium trilogy) were sold in the United States and Great Britain, and another 20 million between Germany, France, Spain, Italy and the Netherlands (Rembe 2012, 6). ${ }^{2}$ Thus, I began to explore ways in my political science classes of how to incorporate the text in my teaching. The W'International courses have been perfect laboratories for this kind of explorative pedagogy, which combines a professor's disciplinary expertise and a unique subject matter, with a study abroad component.

The delivery of course content included lectures on the material and group discussion sessions, with the first five to six minutes of each class devoted to a short video clip having something to do with Swedish culture, politics, or fiction. For example, one short clip included a 60 Minutes interview with author Stieg Larsson; another, a clip of the food scene in Gothenburg. The purpose was to introduce features of Swedish culture, while still saving requisite time for the crime fiction literature. Additionally, each class included a short "reading quiz" for that day's readings. The class met once a week, for 50 minutes, and usually anywhere from 50-70 pages of reading was assigned, enabling us to get through three novels over a period of about four months. Besides reading quizzes, other forms of assessment included short multiple choice exams, and an essay exam which counted toward the final. Following the final examination during the first week of May, we departed for Sweden roughly two weeks later.

The idea of traveling to Sweden to retrace the steps of a Swedish crime novel is not entirely distinctive, and the academic study of crime fiction is itself not unique. Whole conferences have been devoted to the study of Scandinavian crime fiction, and "crime fiction" tours are becoming popular tourist attractions for natives and visitors alike to the region. As Chris Graham, an English travel agent who specializes in Sweden, noted in 2011: "We get calls every week from people who have read the Larsson books. So many people have read them now and the films have been really popular back in the UK, so it's a great way to get people interested in the country" (Rogers 2011).

\footnotetext{
${ }^{1}$ While we wanted to travel to Ystad, it was too expensive and time-consuming for just a ten-day tour. It was easier to travel to Gothenburg, and then north to Fjällbacka.

${ }^{2}$ While Sweden perhaps gets most of the credit for starting the Scandinavian crime fiction trend, that popularity was accelerated by exposure through film, especially the reproduction of The Girl with the Dragon Tattoo which starred Daniel Craig, but also BBC's Wallander series, and the Danish-Swedish television series The Bridge, which premiered on the American streaming service Hulu.2 Gunhild Agger argued that this exposure, "means that mediated Scandinavian crime culture is no longer self-contained, only oriented to a domestic audience, but that it has grown into a contributor to global crime culture" (2010, 2).
} 
For foreign readers especially, crime fiction offers a peek into what might be an otherwise impenetrable society. Mark Lawson of the Guardian noted that "observation and evidence are crucial to the investigation of a crime," which lends itself to excruciating and seeming inane details about the society along the way, such as descriptions of "menus, train timetables, fashion labels, shops, [and] newspaper stories. As a result, good crime novels become a case-file of their times" (2012).

What sets this study abroad experience apart from the popular "tourist" crime fiction walks is the academic rigor which preceded the study abroad. The W'International evaluated crime fiction within the various political and social contexts in which it was written. This approach combined comparison between texts, and discussions of modern societal trends in Sweden. And while there has been a great deal of academic scholarship on crime fiction in Sweden and beyond, I am not aware of any American study abroad experience which combined the academic study of Swedish crime fiction with a travel component such as this. ${ }^{3}$ In other words, this study abroad experience sought to join the best of both worlds: an academically rigorous classroom experience, combined with a travel component that went beyond mere tourism.

\section{The "Other" in Scandinavia}

Many Swedish authors have highlighted immigration as a critical problem to be addressed in their fiction. The political traumas of the 1990s and 2000s, such as the collapse of the Soviet Union or the rise of the Arab Spring, coupled with the political and economic dynamics of the European Union, provide a key backdrop to much of modern crime fiction. Subsequently, the addition of the foreigner to the novel gives important context for a very real political challenge that much of Scandinavia is currently facing, especially Sweden. The crime fiction novel implies a number of questions about who or what is effectively "Swedish", and who exists outside those confines.

One of the most crucial lessons nearly all students learn in study abroad is the feeling at some point or another of being an outsider, or stranger, to a place. The street signs look different, maybe the food is strange, and people speak in an unfamiliar language. Incidentally, this is also a major theme in Swedish crime fiction. In Anderson, Miranda, and Pezzotti's excellent work on foreigners in crime fiction, they note that: "The exotic and the foreign are the quintessence of mystery. The 'Other' - and the 'Unknown' - arouse feelings of curiosity and fear. They demand to be encountered, investigated, decoded, and possibly, rejected" (Anderson et al., 2012, 1). To quote Edward Said, the foreigner represents a version of "Orientalism": "There are Westerners, and there are Orientals. The former dominate; the latter must be dominated..." (1994, 36). While not all foreigners appearing in Scandinavian crime fiction exist to be "dominated," it is certainly true that many foreign characters exist in opposition to "normal" Swedes, Danes, or Norwegians.

The integration of the "foreign" within Swedish society has been complicated by a recent influx of refugees from the Middle East and Africa, coupled with labor mobility which developed as a consequence of the European Union, bringing workers from Eastern and Central Europe. Recently, the coastal city of Malmö has gained international attention as the supposed battleground in the debate over immigration in Europe, with one British politician branding it the "rape capital" of

\footnotetext{
3 There is a crime fiction course run by DIS, which operates out of Denmark, and has a classroom component and study abroad experience in Stockholm and Copenhagen. More information can be found here:

https://disabroad.org/stockholm/courses/scandinavian-crime-fiction/
} 
Europe, and casting blame on foreigners for this uptick. In April 2017, a foreign-born terrorist drove a lorry truck into a crowded shopping district in Drottningattan, a pedestrian shopping district in central Stockholm, killing four. This has created severe political tensions, and fomented a growing, far Right, anti-immigrant political movement within Sweden and beyond its borders. As Kerstin Bergman's work has shown, "Europeanization" has replaced the welfare state as crime fiction writers' new target for concern. "[G]lobalization," Bergman wrote, "and largely, Europeanization... have become the new center of focus" $(2012,302)$.

The concern over a more "global" Sweden among Swedish citizens is grounded in the evolution of Swedish society. In 1960, only 4\% of the entire Swedish population was foreign born, and by 2006, roughly 13\% were (Westin 2006). The latest figures indicate that as of 2017, 17\% of Sweden's population is foreign-born, and roughly $30 \%$ of the population are of foreign-descent. There is a growing number of immigrants from the Middle East and North Africa; countries such as Somalia, Iran, and Iraq, populations with vastly different cultures and religious traditions. Immigrant growth has also included peoples from the former Yugoslavia (roughly 135,000) and Poland (roughly 85,000), and while they might seem to be more connected by a shared European experience, these groups too still face status as outsiders. Perhaps surprisingly, the role of immigrants from post-Soviet spaces and much of Eastern Europe has been rather muted. In a study of Russian and post-Soviet immigrants (excluding the Baltics), Olofsson and Malmberg found a surprisingly low number of these immigrants settling in Sweden. "According to our results migration from the former Soviet republics to Sweden is still surprisingly small despite the proximity between the two countries and the rather large income differentials" (Olofsson \& Malmberg 2011, 112). This included a general weak market for labor, low amounts of intermarriage with Swedes and a lack of community among Russians and post-Soviet groupings within Sweden.

Though it might be rash to paint the picture that Swedish culture is fundamentally in peril, it is clear from many crime fiction novels that the internal and external dynamics of migration create tension, and thus serve as a natural plot point in the fiction. It is also important to note, however, that the largest group of non-natives in Sweden are still and have always been Finns, not far off refugees from the Middle East. And despite their shared border and close proximity, Finns themselves have been viewed as outsiders to Swedish culture. To use one example, the SwedishFinnish dynamic plays out brilliantly in Lars Kepler's novels about detective Joona Linna, a Swedish citizen with a "faint Finnish accent" who occasionally acts and speaks just a little too Finnish.

\section{The Immigrant and the Foreigner in Swedish Crime Fiction}

I assigned three texts to be read over the fifteen, 50-minute class periods: Mankell's Faceless Killers, Larsson's The Girl With the Dragon Tattoo, and Camilla Läckberg's The Ice Princess. Each book dealt in some way with the theme of the "foreigner" or the "Other", but also offered differing perspectives on the question. Moreover, the settings of each text differ, from the large city of Stockholm represented in Larsson's work, the medium-sized outpost of Ystad for Mankell, and concluding with the small fishing village of Fjällbacka in the case of Läckberg's work.

\section{Henning Mankell and the 'Other'}

Though Swedish crime fiction as a literary genre dates back to at least the 1960s, popularized by the writing duo of Maj Sjowall and Per Wahloo, it received renewed interest with the success of 
Henning Mankell's Wallander series. Mankell's first book, Faceless Killers, opens with a murder in a small farming village outside of the southern town of Ystad. Detective Kurt Wallander is tasked with solving the crime, as allegations against immigrants and their criminal proclivities become the subtext for the plot. Wallander finds himself embroiled in the controversy. On the one hand, Wallander is uncertain that an immigrant had anything to do with the crime. Wallander and his department are accused of coddling, or shielding, the immigrant community throughout the investigation. In one particular scene, Wallander is deeply shaken by the cold-blooded murder of a Somali refugee at the hands of a white supremacist (2003, 159-160). On the other hand, he is hardly a progressive on the issue, and has a difficult time, for example, coming to terms with the fact that his daughter is dating a black man from Africa. Wallander, in a discussion with the prosecuting attorney on the case, reflected on the changing social landscape of his community, noting: "It's coming. Unfortunately, I guess I'm supposed to say. But the differences between the big city and the countryside have been almost erased. Organized crime is widespread in Malmö. The open borders and all the ferries are like candy for the underworld" $(2003,131)$. As it turns out, two immigrants did indeed kill the elderly couple. The crime was an act of opportunity, when two Czech men see an elderly gentleman carrying thousands of dollars in cash out of the bank. They find his address, and proceed to kill him and his wife. The wife, who in her dying words whispered foreigner, was right all along.

Faceless Killers plays an interesting trick on the reader, though. All along, you do not want the racists to be right, that an immigrant could have committed such a crime. Indeed, there is a great deal of sympathy embedded throughout the text for the plight of the immigrant. Wallander is similarly tricked: "[W] hen Erik Magnusson came into the picture, we desperately wanted him to be the murderer. But he wasn't. So we got a pair of foreigners after all. And the wretched Somali died for no good reason" (2003, 279). Had Magnusson, whom Wallander suspected of being the murdered man's bastard son, been the killer, the book would have concluded with a tidy ending, and reminded us that immigrants are good people after all and pose no threat. Of course, most immigrants are good people. But other immigrants commit murder. Rather than feeling good about the state of Sweden, and the town of Ystad, we are left at the conclusion of the text with a host of questions about open borders, racism, and immigration that are not easily resolved. ${ }^{4}$

\section{Larsson's Girl with the Dragon Tattoo}

The second text for the course was Stieg Larsson's The Girl with the Dragon Tattoo, the book which ignited the current Swedish crime fiction craze. The novel tells the story of Lisbeth Salander, a private investigator, and Mikael Blomkvist, a journalist, hired to solve the 30-year old mystery of the disappearance of a young girl named Harriet Vanger. Unlike Faceless Killers, Larsson's book does not tackle the immigration issue head on. However, the trilogy does explore that notion of the foreigner and the 'Other' throughout. A prime example of this is Blomkvist's experience in

\footnotetext{
${ }^{4}$ Mankell's second book, Dogs of Riga, further explored the idea of borders, and again, reflects on the experience of immigrants from Central and Eastern Europe. Mankell's Dogs of Riga takes place following the collapse of the Soviet Union. Latvia and Latvians exist as foreign "Others" within the text. The Dogs of Riga is an interesting work of crime fiction because the protagonist (Wallander) is actually the foreigner in this particular case. While we see Latvia from his (Swedish) perspective, he simultaneously spends much of the book as the outsider. Though this particular text was not used in the course, it would be well worth it to consider its lessons for students completing a study abroad, especially Wallander's feelings of alienation, fear and distrust.
} 
Hedestad, the fictional town in the frigid Norrland, where he is summoned to solve the Vanger mystery. As a Stockholm resident, Hedestad represents a great unknown to Blomkvist. Larsson writes: "High banks of snow presented a picturesque contrast to Stockholm. The town seemed almost like another planet, yet he was only a little more than three hours from Sergels Torg in downtown Stockholm” (2009, 63).

The book also introduces a number of foreign characters to the text, including Dragan Armansky, an ethnic Croatian, with Swedish citizenship and mixed ancestry. Larsson wrote:

...Armansky was born in Croatia fifty-six years ago. His father was an Armenian Jew from Belorussia. His mother was a Bosnian Muslim of Greek extraction... His passport confirmed that he was a Swedish citizen, and his passport photograph showed a squarish face, a strong jaw, five-o'clock shadow and greying temples. He was often referred to as "The Arab," although he did not have a drop of Arab blood. He looked like the stereotypical local boss in an American gangster movie... (2009, 28).

Larsson's description of Armansky hinges on the notion that while Armansky is technically Swedish, his looks and childhood belie that point. He's a foreigner (an Arab) without being an Arab. He is described as Serbian in one passage, but is not actually Serbian. Though a successful businessperson and CEO, he "looks" like a gangster. The description of Armansky as not essentially Swedish is a reminder of that tension reflected in modern Swedish society, even though one of the largest immigrant groups includes those from the former Yugoslavia.

The idea of "foreign" ancestry is central to the entire trilogy, especially as details emerge about Lisbeth Salander's childhood. Salander is the central character throughout the text, the "girl" with the mysterious dragon tattoo, and unusual quirks and social anxieties. As is revealed in the second book of Larsson's trilogy, The Girl Who Played with Fire, Salander is the product of a mixed-marriage so to speak, part Swedish and part Russian. Her father, Alexander Zalatšenko, plays the character of the perfect 'Other': he is Russian, and a maniacal sociopath, who tries to have his own daughter killed. (She, of course, tries to kill him first). Nestigen and Arvas in their great essay "Others Knowing Others" remarked that: "Like other criminals from Eastern European countries portrayed in contemporary Scandinavian crime fiction, Zalatšenko is one more military professional trained by the Red Army: he is ruthless, violent, intelligent and a skillful manipulator" (2012: 134). That Salander is Zalatšenko's offspring adds another dimension to her unique and at times bizarre behavior, from her many tattoos, her piercings, her curt personality, and her complete disinterest in food. She is a Swede who is a foreigner in her own country. That she gets along well with Mikael Blomkvist - who himself becomes an outcast in his native land - is not surprising.

\section{Läckberg, Fjällbacka and The Ice Princess}

The third text used in the course was Camilla Läckberg's The Ice Princess. Läckberg is one of the many Swedish authors who have benefited from the success of The Girl with the Dragon Tattoo series. Though published in Sweden one year before Larsson's text, the popularity of the Millennium trilogy - and the accompanying Hollywood film starring Daniel Craig - opened a channel for other Swedish authors to gain maximum exposure in Europe and the United States. Set in the tiny fishing village of Fjällbacka, Läckberg's story is driven by Erica Falck, a journalist who moves back to her hometown to settle the estate of her parents, who had recently passed away. On her first day back, a 
dead body is found frozen in a bathtub, that of a young woman whom Erica knew from growing up in the village. Erica is tasked by the deceased's parents to investigate further, using her journalistic skills to uncover the truth behind the death.

Läckberg's work - unlike the other texts used in the course - is largely apolitical. The story is detached from the immigration narrative which pervades Mankell's work, and which is partly present in Larsson's texts. However, what Läckberg's book does accomplish is using Erica as something of an "outsider" to understand this small town. Yes, she might have grown up in Fjällbacka, "but that felt like a whole lifetime ago" (2011, 8-9). As the mystery unfolds, deep secrets involving class, alcoholism, and sex bubble to the surface. Erica is caught in the middle of these conflicts, as someone who appreciates the charms of life in a small town, but also the dangers. "You should never underestimate the need not to make waves in a small town," said Patrik Hedström, the local police detective, and Erica's soon-to-be husband (2011, 376-377). There are no immigrants in Fjällbacka, and only the occasional tourist during the summertime. And yet, a number of heinous crimes take place, for reasons that have less to do with complicated political motives, or foreigners, and more to do with protecting reputations, and "saving face." There is actually a criminological lesson in all of this: that those who are most likely to do us harm are often those we know, not a dangerous "Other." This does not make violence by immigrants any less troubling, or absolve us from thinking hard about the implications that may arise from freer borders. But Läckberg's book does put into perspective that the cause of a violent crime may not lend itself well to wherever our political sympathies may lie. ${ }^{6}$

\section{Conclusion}

The use of fiction to make sense of politics is not a new approach. Scholars of various disciplines and subfields have long noted the connection between literature and contemporary politics. Marisol Morales-Ladrón, in her essay on novels written during the period of sectarian violence in Northern Ireland known as the "Troubles", argues that literature often includes "actual or realistic political facts; the portrayal of characters who feel... responsible for the social, political or historical contradictions of society." Moreover, such literature is a "depiction of the conflict in terms of pressure of the community on the individual; and [an] exploration of questions of identity" (2006, 60). Likewise, in an article on the role of fiction in understanding nuclear war, Jacqueline Smetak notes:

We need, instead, to reexamine how and why we teach what we choose to teach. We need to believe, as Ohmann puts it, that 'literature doesn't happen in an autonomous realm of culture, but responds and participates in the whole of history.' Literature is, finally about something, something other than itself. We need to reexamine what canonized texts might really have been saying, historically, what factors cause them to express certain things in the ways that they do $(1990,58)$.

Likewise, there are many themes that can be extracted when reading and teaching on Swedish crime fiction. Larsson's work, for example, has been instrumental in working through issues such as

\footnotetext{
5 This is also true not only in Lisbeth Salander's case, but also Harriet Vanger's.

${ }^{6}$ Though Läckberg's book is not expressly political, it still deals with themes that social scientists may find important, such as sexual assault, physical abuse in a marriage, out-of-wedlock births, and alcohol abuse.
} 
far-right extremism, violence against women, and sexual assault, among others. And historically speaking, the Swedish welfare state itself has been a common target of criticism. (In Larsson's text, it is a Swedish civil servant who ultimately abuses his position to sexually assault Lisbeth Salander). The theme of the course on Swedish crime fiction dealt overwhelming with the tensions of being a "foreigner" or an "outsider"; in Mankell's case, how society reacts when feeling that immigration is changing society, and in Larsson's text, how two relative outsiders, one (Blomkvist), a controversial journalist, and the second (Salander), an unusual private investigator and hacker, work together to solve a mystery. In Läckberg's The Ice Princess, Erica Falck becomes something of a foreigner in her own hometown, an outsider tasked with making sense of what is at times an impenetrable community to navigate.

Students on a study abroad might have these same feelings of being outsiders. They are literal foreigners in this case, unsure of the local language and customs, and learning how to adjust on the fly. The classroom component of the course, likewise, captures what is a pivotal moment in Swedish society - how to cope with a rapidly changing society, influenced by varying patterns of immigration, an influx of recent refugees and increased labor movement wrought by the European Union. Combining the academic study of Swedish crime fiction - with emphasis on the "foreign" subject - with immigration trends, is one approach to studying modern Sweden. As one student in the class later noted: "Analyzing the interactions between different ethnic groups and socioeconomic groups within the novels gave... students a chance to see how the political policies on immigration can affect a nation's social climate. Whereas a textbook could offer the same insight, using novels to do so kept me very much engaged within the learning process. I would quickly sign up for a course similar to this one (2017: Student Interview 1).

Other students shared that the novels made the landscape and culture less 'foreign' to them. A student remarked: "The books that we read... helped prepare [us] for Sweden because they were very interesting and helpful. When we went on tours from the books we read, we saw the characters' locations when we were reading the books. The books also helped show the culture of Sweden throughout the novels" (2017: Student Interview 2). Another positive comment about the experience was echoed by a different student, who noted in her response that, "reading crime fiction novels prepared me to travel to Sweden in [that] it helped me understand the culture of the people, and the places that we went. I was able to have background knowledge of the sites and locations that we traveled to before we even went..." (2017: Student interview 3).

While most of the remarks were laudatory of the class design, the students also pointed out that additional non-fiction monographs, or something like a travel guide - with some background facts and information - could be a good supplement to the crime fiction. In speaking to fellow colleagues about the course, they questioned whether the fiction might be too "dark," with the scenes involving violence and sexual abuse too great. In retrospect, I wish I would have included more than just a "trigger-warning" type message when discussing these issues, and went more indepth on some of the women's rights themes in Larsson's and Läckberg's work. Indeed, an entirely different course centered on women's rights and feminism could be developed using these same texts. 
But overall, this experiment of highlighting the foreign "Other" through crime fiction, coupled with a foreign travel component, was successful. In part, Wingate's innovative W'International program provides a venue to use creative course content to explore a specific theme in this manner. And although in this course Swedish crime fiction was used as a backdrop to discuss Swedish politics and society, presumably this framework could be applied at any institution with a study abroad program. As another student noted: "A course like this could definitely be replicated for another W'International class..." (2017: Student interview 4). In other words, this type of course could be reproduced with a focus on other countries, using crime fiction as a base to explore a multitude of themes. It is an approach that worked for Wingate, and could work for any professor interested in approaching important questions in the social sciences from a different vantage point.

\section{Works Cited}

Agger, Gunhild. 2010. "Approaches to Scandinavian Crime Fiction. Crime Fiction and Crime Journalism In Sweden. Working Paper no. 15. http://www.krimiforsk.aau.dk/uk/awpaper/Agger_Approaches ToScandinavienCrimeFiction.w15.pdf.

Ames Paul. 2010. "Sweden has Murder on the Brain." Public Radio International. https://www.pri.org/ stories/2009-10-14/sweden-has-murder-brain.

Anderson, J., C. Miranda \& B. Pezzotti (eds). 2012. The Foreign in International Crime Fiction: Transcultural Representation. New York: Continuum.

Bergman, Kerstin. 2012. "Beyond Stieg Larsson: Contemporary Trends and Traditions in Swedish Crime Fiction." Forum for World Literature Studies. 4(2), 291-306.

Läckberg, Camilla. 2011. The Ice Princess. New York: Free Press Publishing.

Larsson, Stieg. 2009. The Girl With the Dragon Tattoo. New York: Alfred Knopf.

Larsson, Stieg. 2010. The Girl Who Played With Fire. New York: Alfred Knopf.

Lawson, Mark. 2012. "Crime's Grand Tour: European Detective Fiction.” The Guardian. 26 October.

Mankell, Henning. 2003. Faceless Killers. New York: Vintage Books.

Mankell, Henning. 2001. The Dogs of Riga. New York: Vintage Books.

Morales-Ladrón, Marisol. 2006. "Troubling Thrillers: Between Politics and Popular Fiction in the Novels of Benedict Kiely, Brian Moore and Colin Bateman.” Estudios Irlandeses, 1, 58-66.

Nestingen, Andrew. 2012. "Others Knowing Others: Stieg Larsson's Millennium Trilogy and Peter Høeg's Smilla's Sense of Snow." In The Foreign in International Crime Fiction. (Eds.) J. Anderson, C. Miranda, \& B. Pezzotti. (124-136) London: Continuum.

Olofsson, Jenny \& Gunnar Malmberg. 2011. "When Will the Russians Come? On Post-Soviet Immigration and Integration in Sweden." International Migration. 49(4), 93-117.

Potter, Tim and Amy Renee Leiker. 2006. "Three Charged in Kansas Plot to Bomb Homes, Worship Center for Somalis." Kansas City Star. 14 October.

Rembe, Annika. 2012. "Sweden Beyond the Millennium and Stieg Larsson." Swedish Institute. (pp. 127). https://issuu.com/swedish_institute/docs/sweden_beyond_the_millennium.

Rogers, Richard. 2011. "The Sound of Silence: The Boom in Swedish Crime Fiction." The Observer (UK), 13 March.

Smetak, Jacqueline. 1990. "So Long, Mom: The Politics of Nuclear Holocaust Fiction." Papers on Language and Literature. 26(1). 41-59.

Said, Edward. 1994. Orientalism. New York: Vintage Books.

Smith, Micah. 2016. "3 Held in Bomb Plot Against Somalis in Kansas." New York Times, 14 October.

Westin, Charles. 2006. "Sweden: Restrictive Immigration Policy and Multiculturalism." Migration Policy.Org. 1 June. https://www.migrationpolicy.org/article/sweden-restrictive-immigration-policyand-multiculturalism.

Student Interview 1. Conducted by email 5 May 2017.

Student Interview 2. Conducted by email 1 May 2017. 
Student interview 3. Conducted by email 5 May 2017. Student interview 4. Conducted by email 2 May 2017. 